\title{
Katja Lihtenvalner \\ »PRED TREMI DESETLETJI JE BILA EVROPA DRUGAČNA« Srečanje z Lauretto Macauley
}

S predsednico Združenja afriških žensk v Grčiji Lauretto Macauley smo se srečali letos avgusta. Pričakala nas je na sedežu organizacije v atenskem predelu Abelokipi.

Ogromen prostor je polepljen s fotografijami, slikami in zemljevidi. Afriška skupnost poskuša simbolično ostati povezana z domovino, ki jo mnogi le redko obiščejo.

»Ko sem jaz prišla sem, so bili drugačni časi za nas, migrante. Bilo je lažje. Vizume smo dobili zlahka. Ni bilo nevarnih potovanj po vsej Afriki prek suhe puščave ali voženj po Mediteranu s plastičnimi čolni, « nam pojasni 58-letna Afričanka, ki se je v Grčijo iz rodne Sierre Leone preselila pred tremi desetletji. »Odšla sem kot večina nas: želela sem si boljše življenje. Takrat je bila Evropa drugačna, « še pove.

Lauretta Macauley je mati enega otroka. Ob prihodu v Grčijo se je najprej zaposlila kot gospodinjska pomočnica, kasneje pa ob službi prevzela krmilo največje ženske afriške organizacije v Grčiji.

\section{TRG DELA ZA MIGRANTKE V GRČIJI OMEJEN}

Pred desetimi leti se ji je porodila ideja, da bi ustanovila Združenje afriških žensk v Grčiji. »Težave, ki jih imajo ženske tukaj, so vedno večje. Nimajo urejenih dokumentov, ne morejo najti službe, potem so tukaj rasistični napadi, pa težave, ki jih ima vsaka ženska doma s svojo družino in možem. Poskušamo jim pomagati pri soočanju z vsakodnevnimi težavami in ovirami. Želimo pa jim tudi pomagati pri integraciji v grško družbo, « opiše delo organizacije. »Ženske in posebej migrantke med ekonomsko krizo težko najdejo dostojno službo. Trg dela je v Grčiji skrajno omejen, « ugotovi. Simpatična in topla Afričanka pove, da so migrantke v moderni Grčiji prisiljene delati kot gospodinjske pomočnice. »Drugačna usoda, če sploh dobijo službo, jih skoraj ne čaka,«strne.

V Združenje afriških žensk se zatekajo tudi dekleta, ki so žrtve trgovine z ljudmi, saj mnoge izmed njih končajo v prisilni prostituciji. »Tukaj, v Atenah, so to po večini Nigerijke, « nam pove. V grški prestolnici so posebej afriške prostitutke prisiljene v delo na 
cesti. Srečujemo jih v jutranjih in nočnih urah na obljudeni aveniji Patisijon. »Če jim uspe pobegniti, pri nas najdejo zaščito. Ne uspe pa vsem. Zaradi težkih življenjskih razmer mnoge izmed njih druge možnosti ne vidijo, « meni sogovornica.

V Grčiji, ki se ubada z veliko humanitarno katastrofo domačega prebivalstva, od katerih kar četrtina živi pod pragom revščine, brezposeln pa je vsak tretji Grk, je življenje migrantov potisnjeno na družbeni rob. Mnogi so prisiljeni v prekarno delo, sezonska slabo plačana dela ali pa so prepuščeni izsiljevanju delodajalcev, o čemer lahko beremo vsak dan. »Če me ženske vprašajo za nasvet o svoji prihodnosti, jih spodbujam, naj se preselijo, če tako nameravajo, « pove predsednica grškega Združenja afriških žensk.

V organizaciji skozi leto prirejajo več različnih dogodkov. Tako so 8. septembra 2014 organizirali konferenco z naslovom »Nevidno nasilje - reši se iz začaranega kroga«. Izvajajo tudi delavnice in festivale ter družabne dogodke (med drugim tudi modne revije in dobrodelne zabave), na katerih se lahko migrantke med sabo spoznavajo in družijo, odprti pa so tudi za širšo javnost. Organizacija ima članice iz več kot desetih afriških držav.

\section{IZPOSTAVLJENE POLICIJSKEMU NADLEGOVANJU}

V organizaciji se članice ukvarjajo tudi z gledališčem zatiranih Augusta Boala. Ko so se lanskega septembra pripravljale na predstavo, se je zgodil incident, ki grške javnosti ni pustil nedotaknjene. Tri Afričanke, med drugim tudi našo sogovornico, so aretirali grški policisti pod pretvezo, da »delujejo sumljivo«. Ironično je, da so se ženske ravno vračale z vaj za predstavo z naslovom »Proti rasizmu že v zibelki«. Četudi so vse ženske imele pri sebi veljavne dokumente za bivanje, jim grški policisti niso prisluhnili.

»Potem, ko se niso zmenili za naše opozorilo, so nas odpeljali na policijsko postajo Petru Rali in nas tam zaprli v ječo skupaj z moškimi, « pripoveduje Lauretta. Afričanka pove, da se ji je zdelo neprimerno, da so jih zaprli skupaj s skoraj 40 moškimi, zato se je uprla in poklicala policiste, naj ukrepajo. »Utihni, prasica. Tukaj je Grčija. Če bi bila moški, bi te že zgrabil za lase, « je bil odgovor enega izmed njih. Policisti so podobno retoriko ubrali tudi do odvetnice, ki je prišla ženskam pomagat, in ji grozili, da jo bodo aretirali.

»Izjemno travmatična izkušnja, « nam pove. Nasilje grških policistov sicer že zdavnaj ni več tabu tema. Pred nekaj tedni so v središču Aten aretirali tudi predsednika pakistanske skupnosti Javeda Aslama. Ta zgodba bo epilog dobila na sodišču, saj se je pakistanska skupnost v Grčiji odločila, da bo proti policistom zaradi ksenofobnega in rasističnega vedenja vložila tožbo.

»Zame je ta zgodba končana. Nočem je več pogrevati. Grški policisti so nasilni ter posebej radi preiskujejo in aretirajo migrante. To so njihove glavne tarče, « nam pove mila in prijetna sogovornica.

V Grčiji sicer v javnosti redko zasledimo, da bi bile žrtve ksenofobnega nasilja migrantke. Najbolj odmeven primer napada na migrantko letos je zgodba 50-letne Bolgarke Anastasije, ki so jo njeni delodajalci brutalno pretepli. Druge zgodbe iz (ne)legalnih 
atenskih bordelov, pekarn To Horiatiko, pa iz življenja migrantk, ki brez zdravstvenega zavarovanja in socialne zaščite skrbijo za grške upokojence, pa pogosto ostanejo skrite za štirimi stenami.

Društva, kot je Združenje afriških žensk v Grčiji, ostajajo edina svetla točka, kjer lahko ženske v težavah najdejo zatočišče, se povežejo z domovino in okrepijo svoje samozavedanje.

Helenska republika, ki se danes kar ne zmore izvleči iz ekonomske, socialne in politične krize, je bila včasih veliko bolj odprta in dinamična pri sprejemanju migrantov. Danes se ti spopadajo z enakimi težavami kot domačini, pri tem pa jih čakajo še birokratske ovire, grožnje z nehumanimi namestitvenimi centri, pa policijsko in rasistično nasilje ter zaprte evropske meje. Begunska kriza je po dolgih letih vojn na Bližnjem vzhodu razmere še dodatno poslabšala. Hkrati je na preizkušnjo postavila vrednote sodobne evropske kulture, ki se rada ponaša s tem, da je enakopravna, multikulturna in odprta. 